\title{
Hubungan antara Tayangan Drama Serial Korea X dengan Minat Mahasiswa menjadi Reporter
}

\author{
Azka Muzakiah*, Wulan Trigartanti \\ Prodi Public Relation, Fakultas Ilmu Komunikasi, Universitas Islam \\ Bandung, Indonesia. \\ *azkamuzakiah@gmail.com,gartanti@yahoo.com
}

\begin{abstract}
The world has been faced with changes in the digital era, especially in the field of information communication which makes it easier for humans to access various information. whether in the form of news, advertisements, radio broadcasts, film shows to dramas. Drama shows, especially dramas from Korea, are very popular among the public, seen from the birth of the term Korean wave. The various themes raised made the storyline more diverse, one of which was the $\mathrm{X}$ drama series which picked up a reporter's story. So the researchers are interested in researching the $\mathrm{X}$ drama shows with the audience's interest in becoming reporters. The purpose of this study was to determine the relationship between the $\mathrm{X}$ drama program and the audience's interest in becoming a reporter. The theory used is mass communication process theory, media exposure theory, and social learning theory. The method used is a quantitative correlational approach with data collection techniques through questionnaires, observation, and literature. The questionnaire was distributed to 79 respondents at the Faculty of Communication Unisba 2017 and analyzed by statistical tests with the SPSS application. The results of this study obtained a correlation coefficient with the number 0,772 it can be interpreted that there is a strong relationship between drama shows and the variable of interest in being a reporter
\end{abstract}

Keywords: Impressions, Korean Drama, Interests, Reporter.

Abstrak. Dunia telah dihadapkan oleh perubahan era yaitu digital, khususnya pada bidang komunikasi informasi yang menyebabkan manusia menjadi lebih mudah untuk mengakses berbagai informasi. baik dalam bentuk berita, iklan, siaran radio, tayangan film hingga drama. Tayangan drama khususnya drama dari negara Korea sangatlah populer dikalangan masyarakat, dilihat dari lahirnya sebutan yaitu gelombang Korea. Berbagai tema yang diangkat membuat alur cerita semakin beragam, salah satunya drama serial $\mathrm{X}$ yang mengangkat cerita cerita reporter. Maka peneliti tertarik meneliti mengenai tayangan drama $X$ dengan minat penonton menjadi reporter. Tujuan penelitian ini untuk mengetahui hubungan antara tayangan drama $\mathrm{X}$ dengan minat penonton menjadi reporter. Teori yang digunakan yaitu teori proses komunikasi massa, teori terpaan media, dan teori pembelajaran sosial. Metode yang digunakan adalah kuantitatif pendekatan korelasional dengan teknik pengumpulan data melalui kuesioner, observasi, dan studi pustaka Kuesioner disebar kepada 79 responden di Fikom Unisba angkatan 2017 serta dianalisis oleh uji statistika dengan aplikasi SPSS. Hasil penelitian ini diperoleh koefisien korelasi dengan angka 0,772 yaitu dapat diartikan terdapat hubungan yang kuat antara tayangan drama dengan variabel minat menjadi reporter

Kata Kunci: Tayangan, Drama Korea, Minat, Reporter. 


\section{A. Pendahuluan}

Seiring perkembangan zaman, dunia telah dihadapkan oleh perubahan era yaitu digital. Faktanya saat ini dunia sudah memasuki era revolusi industri 4.0 yang ditandai oleh peningkatan perkembangan sistem digital. Perjalanan teknologi yang sangat pesat selaras pula dengan bertambahnya kebutuhan manusia dari tahun ketahun. Teknologi yang terus berkembang tidak ada hentinya mampu melahirkan Interconnected Network atau biasa disebut Internet. Peran Internet sangatlah besar terhadap berbagai sektor kehidupan di masyarakat. Internet mampu menghubungkan semua penggunanya tanpa ada batas waktu, tempat, dan usia dengan waktu yang cepat.

Hal ini membuat teknologi melahirkan masyarakat yang semakin melek kepada teknologi serta menjadi suatu kebutuhan di masyarakat. Seiring berjalannya waktu tidak dipungkiri kebutuhan masyarakat tentu saja semakin bertambah, hadirnya internet membuat semuanya terasa mudah, cepat, dan tepat. Dilihat pada saat ini hampir seluruh sistem kehidupan sudah menggunakan sistem operasi digital. Masyarakat seolah dimanjakan oleh kemudahan yang diberikan membuat masyarakat tergantung dan menjadi pengguna aktif internet.

Dalam berita online Kompas Tekno, diungkapkan bahwa jumlah pengguna internet di Indonesia pada awal tahun 2021 yaitu mencapai 202,6 juta atau 73,7 persen dari total populasi sebanyak 274,9 juta jiwa. Sedangkan disebutkan pula bahwa data pengguna internet terbanyak berada di rentang usia 18 tahun hingga 34 tahun. Rentang usia yang sudah disebutkan diatas termasuk pada rentang usia bagi pelajar, mahasiswa atau sarjana. Dapat dikatakan bahwa rentang usia tersebut merupakan usia masyarakat yang sudah melek pada teknologi digital saat ini.

Perkembangan teknologi digital juga melahirkan media - media digital yang mampu memberikan kemudahan dalam segala aspek kehidupan. Media digital dapat diakses dalam bentuk aplikasi yang msmpu hadir di smartphone, tab, laptop, hingga smart TV. Dengan memanfaatkan internet dan sistem komputer, aplikasi online menyajikan berbagai tayangan hiburan dari mulai film, drama serial, documenter, dan masih banyak lagi. Masyarakat menjadi semakin sulit untuk menolak kemudahan yang ditawarkan. Hal ini membawa perubahan pada kebiasaan masyarakat Indonesia yang sebelumnya hanya mengandalkan televisi saat menonton tayangan, tetapi saat ini sudah banyak aplikasi video streaming yang dapat menayangkan tayangan dari berbagai negara, termasuk Korea.

Dibuktikan dalam Tirto.id, hasil survey pada tahun 2017 menunjukkan bahwa masyarakat Indonesia lebih memilih menonton serial drama Korea dibanding negara yang lain dengan data sebanyak 49,72 persen. Lalu disebutkan pula sekitar 80,61 persen masyarakat Indonesia menyatakan bahwa menyukai serial Korea karena alur ceritanya yang menarik serta tidak bertele - tele. Seiring berjalannya waktu pada tahun 2020 dalam berita online detik.com, pihak Youtube menyatakan bahwa semenjak pandemi Covid-19, jumlah pencarian "Drama Korea" lalu "Korea Drama" hingga "Drakor" mengalami kenaikkan hingga 130 persen jika melihat data pada tahun 2019.

Dari data diatas dapat dikatakan bahwa seiring berjalannya waktu dari tahun ke tahun popularitas drama Korea di masyarakat Indonesia terus meningkat. Ketertarikan penonton pada drama serial Korea dapat disimpulkan berhubungan dengan alur cerita yang diangkat serta pemain yang menarik. Dapat mencakup peran pemain yang menarik hingga aktor dan aktris pemain yang menarik.

Tepatnya pada tanggal 21 Februari 2021 hadir drama korea berjudul X yang mengangkat cerita mengenai reporter. $X$ adalah salah satu drama serial keluaran TV channel asal Korea OCN yang memiliki total 12 episode. Membawakan alur cerita ber-genrekriminal, thriller, fantasi, dan politik drakor ini mengisahkan tentang dua reporter handal yang mengutamakan kejujuran saat bekerja, dan reporter yang sangat pekerja keras dalam menemukan fakta misterius mengenai rencana pembunuhan terhadap presiden. 
Dalam web resmi aplikasi video streaming Viu disebutkan bahwa rating drama Korea berjudul X pada episode pertama memang tidak terlalu tinggi hanya mencapai angka 1,6 persen. Tetapi setelah bertambahnya episode dua, tiga, dan seterusnya, rating $X$ pun terus menerus meningkat. Dibuktikan dalam web resmi Internet Movie Database (IMDb) dicantumkan bahwa rating drama Korea berjudul X mencapai angka 7.3/10.

Alur cerita drama Korea $X$ ini sangat beragam, terselip banyak pesan dan motivasi didalamnya mengenai bagaimana pekerjaan seorang reporter, bagaimana seorang reporter yang harus teguh pada pendirian, bagaimana seorang reporter mengutamakan kejujuran demi mengungkapkan fakta. Bukan hanya itu, tentu masih banyak pula adegan dan persoalan dalam cerita X yang membuat alur cerita menjadi berwarna, contohnya adegan action hingga perpindahan waktu didalamnya .

\section{B. Metodologi Penelitian}

Metode yang digunakan adalah kuantitatif pendekatan korelasional dengan teknik pengumpulan data melalui kuesioner, observasi, dan studi pustaka Kuesioner disebar kepada 79 responden di Fikom Unisba angkatan 2017 serta dianalisis oleh uji statistika dengan aplikasi SPSS. Hasil penelitian ini diperoleh koefisien korelasi dengan angka 0,772 yaitu dapat diartikan terdapat hubungan yang kuat antara tayangan drama dengan variabel minat menjadi reporter.

\section{Hasil Penelitian dan Pembahasan}

Penelitian ini menggunakan studi korelasional yaitu pengujian hubungan antara dua variabel yang diangkat oleh peneliti. Maka penelitian ini dalam upaya menelaah hubungan Tayangan Drama Korea $X$ sebagai (variabel $X$ ) dengan Minat mahasiwa menjadi reporter sebagai (variabel Y). Populasi dan sampel yang dipilih dalam penelitian ini adalah mahasiswa Ilmu Komunikasi Universitas Islam Bandung angkatan 2017. Definisi populasi menurut Sugiono (2012) dalam Riawati \& Hernawati (2016) adalah penyamarataan ciri ciri dan kualitas pada suatu subjek atau objek penelitian yang ditentukan dan ditetapkan oleh peneliti untuk ditelaah lalu ditarik kesimpulan.

Dalam mengetahui seberapa baik konsep pada penelitian ini perlu diukur dan diuji menggunakan uji validitas. Melewati proses yaitu pada setiap instrumen pertanyaan dihitung dengan uji korelasi Rank Spearman, dengan menghasilkan nilai R Hitung pada seluruh item pertanyaan lebih besar dari nilai $\mathrm{R}$ Tabel yaitu 0,186 . Dapat diartikan bahwa seluruh pertanyaan dalam angket dinyatakan valid untuk menguji jawaban responden. Selain itu, dibutuhkan pula pengujian apakah hasil pengukuran konsisten atau tidak yaitu menggunakan uji realibitas.

Alat ukur uji realibilitas pada penelitian ini menggunakan metode Alpha Cronbach's dengan hasil yang baik dikarenakan angka melampaui nilai standar 0,60. Nilai yang dihasilkan pada variabel terpaan media adalah sebesar 0,941 dan variabel minat menjadi reporter adalah sebesar 0,896. Dengan begitu, variabel pada penelitian ini dapat dinyatakan reliable dan dapat dipercaya untuk menguji jawaban responden.

Pertanyaan yang disebar berupa kuesioner kepada responden. Pada bagian data responden kategori jenis kelamin menunjukkan sebagian besar responden pada penelitian adalah perempuan sebanyak 51 orang dengan presentase $65 \%$. Lalu jumlah responden laki-laki sebanyak 28 orang dengan nilai presentase sebesar 35\%, Hal tersebut terbukti dengan kebanyakan penggemar drama korea adalah perempuan.

\section{Pembahasan dan Analisis.}

Penggunaan analisis deskriptif pada pengolahan data dilakukan untuk meninjau, melihat dan menggambarkan objek yang diteliti melalui angka dan menarik kesimpulan fenomena yang tampak pada saat penelitian dilakukan (Putra,2015:73). Pada bagian ini peneliti akan menguraikan dan menganalisis mengenai jawaban-jawaban dari responden mengenai hubungan antara tayangan drama serial korea $X$ dengan minat mahasiswa fakultas Ilmu Komunikasi Universitas Islam Bandung (Unisba) Angkatan 2017 menjadi reporter. Hasil pengolaha data berikut ini akan berpacu pada nilai dalam skala likert 1 sampai 4 untuk makna sangat tidak setuju sampe sangat setuju. 
Skala likert tergolong ke dalam data ordinal. Maka teknik statistik pada penelitian ini menggunakan analisis inferensial nonparametris. Menurut Sugiyono (2019) teknik analisis data statistik melalui analisis inferensial nonparametris adalah pengujian statistik yang dipakai untuk mengolah data ordinal. Disamping itu, penghitungan data dilakukan menggunakan rumus Rank Spearman untuk menguji hipotesis dan korelasi serta bantuan dari aplikasi IBM SPSS Statistic 24 melalui analisis korelasi bivariat. Dalam Suhartanto (2004) Analisis korelasi bivariat adalah sebuah analisis yang menguji korelasi antara suatu variabel dengan variabel lainnya.

Tabel 1. Hasil Analisis Korelasi Bivariat Variabel X terhadap Y

\begin{tabular}{|c|c|c|c|c|c|c|}
\hline Korelasi & \multicolumn{4}{|c|}{ Variabel Minat Menjadi Reporter (Y) } & \multirow[b]{2}{*}{ Hipotesis } & \multirow[b]{2}{*}{ Keterangan } \\
\hline Variabel $(\mathbf{X})$ & $\begin{array}{c}\text { Pearson } \\
\text { Correlations }\end{array}$ & $\begin{array}{c}\text { Tingkat } \\
\text { Hubungan }\end{array}$ & $\alpha$ & Sig & & \\
\hline $\begin{array}{l}\text { Terpaan } \\
\text { Media }\end{array}$ & 0,772 & Kuat & 0,05 & 0,000 & $\begin{array}{c}\text { H1 } \\
\text { diterima }\end{array}$ & Signifikan \\
\hline
\end{tabular}

Tabel di atas menunjukkan hasil pengujian kolerasi bivariat dari hipotesis utama yang diujikan yaitu variabel terpaan media melalui tayangan drama dan minat menjadi reporter. Hasil pengujian di atas adalah hasil mengenai hubungan antara variabel terpaan media yaitu tayangan drama $\mathrm{X}$ dengan variabel minat untuk menjadi reporter. Tabel tersebut menunjukkan nilai koefisien korelasi dengan angka 0,772 yang berada diantara 0,600-0,799. Angka tersebut dapat diartikan bahwa variabel terpaan media melalui tayangan drama ini memiliki tingkat hubungan yang kuat dengan variabel minat menjadi reporter.

\section{Hubungan Tayangan Drama Serial X dengan Minat Menjadi Reporter pada Mahasiswa Ilmu Komunikasi Unisba Angkatan 2017.}

Hasil pengolahan data yang telah dilakukan sebelumnya menghasilkan tanggapan responden yang merupakan Mahasiswa Fakultas Ilmu Komunikasi Unisba Angkatan 2017 secara keseluruhan menyatakan tanggapan yang positif terkait seluruh sub variabel alat ukur pada variabel ini. Hal tersebut berhubungan dengan tanggapan responden terkait pernyataanpernyataan yang menggambarkan minat mereka untuk menjadi seorang reporter. Sebagian besar menyatakan ingin dan memiliki minat untuk bekerja sebagai seorang reporter. Namun, ada pula responden tidak tertarik untuk menjadi seorang reporter.

Berdasarkan teori yang disampaikan Jalaludin Rakhmat dalam Izzatunihlah (2017) bahwa terpaan media terjadi mengarah kepada frekuensi individu dalam membaca majalah atau membaca koran, menonton televisi, menonton film, maupun mendengar radio. Dalam hal ini, adanya tayangan drama $X$ dinilai dapat memberikan informasi terkait kehidupan seorang reporter. Hal tersebut tentu berhubungan erat dengan minat responden untuk bekerja menjadi seorang reporter.

Definisi minat menurut Crow and Crow dalam Abd. Rachman Aboro (1003: 112) dalam Elendiana (2020) minat yakni berhubungan dengan daya gerak yang mendorong kita cenderung atau merasa tertarik pada orang, benda, kegiatan ataupun bisa pengalaman yang afektif yang dirasakan oleh kegiatan itu sendiri. (Elendiana, 2020).

Berdasarkan hasil penelitian, diketahui adanya tayangan tersebut sebagian besar responden memiliki minat untuk menjadi seorang reporter dikarenakan adanya adegan-adegan yang meningkatkan motivasi dan minat. Hal tersebut merupakan adanya hubungan antara terpaan dan minat dari tayangan drama $X$. Namun, sebagian kecil yang tidak berminat untuk menjadi seorang reporter bisa terjadi karena kehidupan seorang reporter yang diceritakan pada tayangan drama $X$ tidak memberikan kesan yang membuat responden ingin menjadi reporter serta tidak terlalu berminat dan tertarik pada bidang tersebut. 
Tabel 2. Hasil Analisis Korelasi Bivariat Sub Variabel Frekuensi (X1) terhadap Minat (Y)

\begin{tabular}{|c|c|c|c|c|c|c|}
\hline Korelasi & Variabel Min & at Menjadi I & eport & er $(Y)$ & & \\
\hline $\begin{array}{c}\text { Dimensi } \\
\text { (X1) }\end{array}$ & $\begin{array}{c}\text { Pearson } \\
\text { Correlations }\end{array}$ & $\begin{array}{c}\text { Tingkat } \\
\text { Hubungan }\end{array}$ & $\alpha$ & Sig & Hubungan & Keterangan \\
\hline Frekuensi & 0,633 & Kuat & 0,05 & 0,000 & $\begin{array}{c}\mathrm{H} 1 \\
\text { diterima }\end{array}$ & Signifikan \\
\hline
\end{tabular}

Hasil pengujian di atas adalah hasil mengenai hubungan antara sub variabel pertama pada variabel terpaan media yaitu frekuensi menonton tayangan drama $\mathrm{X}$ dengan variabel minat untuk menjadi reporter. Dari tabel tersebut, terlihat bahwa nilai koefisien korelasi yang menunjukkan bahwa hubungan antara variabel terpaan media melalui tayangan dramadan minat menjadi reporter adalah sebesar 0,633. Angka tersebut berada diantara 0,600-0,799 yang berarti bahwa kedua variabel tersebut memiliki hubungan yang kuat dan positif.

\section{Hubungan Frekuensi Menonton Drama Serial X dengan Minat Menjadi Reporter pada Mahasiswa Ilmu Komunikasi Unisba Angkatan 2017.}

Hasil pengolahan data yang telah dilakukan sebelumnya menghasilkan tanggapan responden yaitu mahasiswa Fakultas Ilmu Komunikasi Unisba Angkatan 2017 secara keseluruhan menyatakan tanggapan yang positif terkait seluruh sub variabel alat ukur pada variabel ini. Namun, masih terdapat juga sebagian responden yang meyatakan sebaliknya, dalam artian mereka tidak memiliki ketertarikan terhadap tayangan drama tersebut.

Hal tersebut berhubungan secara langsung dengan tanggapan responden terkait pernyataan-pernyataan yang menggambarkan minat mereka untuk menjadi seorang reporter. Sebagian besar responden menyatakan ingin dan memiliki minat untuk bekerja sebagai seorang reporter. Namun, ada banyak pula responden yang menyatakan bahwa mereka tidak tertarik untuk menjadi seorang reporter.

Berdasarkan teori yang disampaikan Well et al (2000:156) dalam Ridhwan (2018) diketahui bahwa frekuensi merupakan seberapa sering tayangan drama $X$ diperhatikan, dilihat, dan didengarkan. Semakin tinggi frekuensi terkena terpaan semakin besar pula peluang pesan tersebut menempel dalam benak penonton dan mendapat perhatian dari penonton. Tanggapan responden pada sub variabel ini memperlihatkan bahwa frekuensi mereka menonton tayangan cukup tinggi. Diperkuat pada bagian hasil analisis data korelasi didapatkan hasil yang menunjukkan bahwa adanya frekuensi yang tinggi menghasilkan hubungan yang signifikan dan kuat dengan minat mahasiswa untuk menjadi reporter.

Namun, disisi lain responden menyatakan tayangan drama tidak membuat mereka ingin menjadi reporter. Hal tersebut sangat bisa terjadi melihat kemungkinan - kemungkinan yang terjadi pada diri responden. Diketahui bahwa seseorang mengamati sesuatu yang dalam hal ini adalah sebuah drama, selanjutnya adalah representasi.

Tabel 3. Hasil Analisis Korelasi Bivariat Sub variabel Metode Penyajian (X2) terhadap Minat (Y)

\begin{tabular}{|c|c|c|c|c|c|c|}
\hline \multirow{2}{*}{$\begin{array}{c}\text { Korelasi } \\
\text { Dimensi } \\
\text { (X2) }\end{array}$} & \multicolumn{4}{|c|}{ Variabel Minat Menjadi Reporter (Y) } & \multirow{2}{*}{$\begin{array}{c}\text { Tingkat } \\
\text { Hubungan }\end{array}$} & \multirow[b]{2}{*}{ Keterangan } \\
\hline & \begin{tabular}{c|} 
Pearson \\
Correlations \\
\end{tabular} & \begin{tabular}{|c|} 
Tingkat \\
Hubungan
\end{tabular} & $\alpha$ & Sig & & \\
\hline $\begin{array}{l}\text { Metode } \\
\text { Penyajian }\end{array}$ & 0,695 & Kuat & 0,05 & 0,000 & $\begin{array}{c}\mathrm{H} 1 \\
\text { diterima }\end{array}$ & Signifikan \\
\hline
\end{tabular}

Hasil pengujian di atas adalah hasil mengenai hubungan antara sub variabel metode penyajian secara mandiri dengan variabel Minat menjadi reporter. Tabel di atas menunjukkan nilai koefisien korelasi dengan angka 0,695 yang berada diantara 0,600-0,799. Angka tersebut dapat diartikan bahwa sub variabel metode penyajian memiliki tingkat hubungan yang kuat dengan variabel minat menjadi reporter. 


\section{Hubungan Metode Penyajian Drama Serial X dengan Minat Menjadi Reporter pada Mahasiswa Ilmu Komunikasi Unisba Angkatan 2017.}

Melihat hasil pengolahan data yang telah dijelaskan sebelumnya didapatkan hasil bahwa responden menganggap sub variabel metode penyajian drama $X$ dinilai sudah baik. Kebanyakan responden manyatakan bahwa drama ini sudah cukup informatif untuk menyampaikan pesanpesan yang berisi informasi-informasi tertentu terkait kehidupan pekerjaan reporter.

Asumsi awal memberi sudut pandang teoritis Bandura dalam Herly (2018) bahwa pembelajaran pada hakikatnya berlangsung melalui proses peniruan atau pemodelan. Maksud dari pemodelan yang disebutkan adalah seseorang yang bisa diamati, dijadikan pelajaran, dan bisa ditiru oleh pengamatnya.

Sejalan dengan teori tersebut, adanya informasi-informasi terkait kehidupan seorang reporter yang ditampilkan pada tayangan drama $X$ ini secara tidak langsung membuat para penontonnya belajar. Mereka yang memahami isi pesan yang disampaikan akan menghasilkan respon tertentu. Dalam hal ini sebagian besar responden berminat untuk menjadi seorang reporter. Hal tersebut menunjukkan adanya hubungan yang signifikan antara metode penyajian tayangan drama $X$ ini dengan adanya minat mahasiswa untuk menjadi seorang reporter.

Tabel 4. Hasil Analisis Korelasi Bivariat Sub Variabel Durasi (X3) terhadap minat (Y)

\begin{tabular}{|c|c|c|c|c|c|c|}
\hline \multirow{2}{*}{$\begin{array}{c}\text { Korelasi } \\
\text { Dimensi } \\
\text { (X3) }\end{array}$} & \multicolumn{4}{|c|}{ Variabel Minat Menjadi Reporter (Y) } & \multirow[b]{2}{*}{$\begin{array}{c}\text { Tingkat } \\
\text { Hubungan }\end{array}$} & \multirow[b]{2}{*}{ Keterangan } \\
\hline & $\begin{array}{c}\text { Pearson } \\
\text { Correlations }\end{array}$ & \begin{tabular}{|c|} 
Tingkat \\
Hubungan \\
\end{tabular} & $\alpha$ & Sig & & \\
\hline Durasi & 0,629 & Kuat & 0,05 & 0,000 & $\begin{array}{c}\mathrm{H} 1 \\
\text { diterima }\end{array}$ & Signifikan \\
\hline
\end{tabular}

Tabel di atas menunjukkan hasil pengujian hubungan antara sub variabel durasi secara mandiri dengan variabel Minat menjadi reporter. Hasil tersebut menunjukkan nilai koefisien korelasi sebesar 0,629 yang berada diantara 0,60-0,999. Angka tersebut dapat diartikan bahwa sub variabel dengan variabel Minat menjadi reporter memiliki hubungan yang kuat dan positif.

Hubungan Durasi Menonton Drama Serial X dengan Minat Menjadi Reporter pada Mahasiswa Ilmu Komunikasi Unisba Angkatan 2017.

Hasil pengolahan data yang telah dilakukan sebelumnya menghasilkan tanggapan responden yaitu mahasiswa fakultas Ilmu Komunikasi Universitas Islam Bandung angkatan 2017 menyatakan bahwa mereka menonton tayangan drama $X$ ini dari awal hingga akhir tayangan. Disamping itu pula sebagian besar dari mereka sudah menonton seluruh episode drama tersebut dari awal sampai akhir. Responden manyatakan bahwa adanya durasi 60 menit dalam setiap episode sudah cukup memberikan informasi yang jelas sehingga mudah untuk menangkap makna yang disampaikan pada drama tersebut.

Hal tersebut menunjukkan adanya tanggapan yang positif terkait sub variabel durasi menonton tayangan drama X. Durasi yang dimaksudkan adalah seberapa lama tayangan drama $X$ diperhatikan, dilihat, dan didengarkan oleh penonton. Durasi dari tayangan drama $X$ untuk menonton dalam satu episode memakan waktu 60 menit. Sehingga penonton akan menerima terpaan tayangan drama $X$ selama satu jam. Melalui durasi waktu yang responden habiskan untuk menonton tayangan drama $X$ tersebut menimbulkan adanya hubungan yang signifikan dengan minat responden untuk menjadi seorang reporter. 
Tabel 5. Hasil Analisis Korelasi Bivariat Sub Variabel Atensi (X4) terhadap minat (Y)

\begin{tabular}{|c|c|c|c|c|c|c|}
\hline Korelasi & \multicolumn{2}{|c|}{ Variabel Minat Menjadi Reporter (Y) } & Tingkat \\
\cline { 1 - 4 } $\begin{array}{c}\text { Dimensi } \\
(\mathbf{X} 4)\end{array}$ & $\begin{array}{c}\text { Pearson } \\
\text { Correlations }\end{array}$ & $\begin{array}{c}\text { Tingkat } \\
\text { Hubungan }\end{array}$ & $\boldsymbol{\alpha}$ & Sig & Heterangan \\
\hline Atensi & 0,710 & Kuat & 0,05 & 0,000 & $\begin{array}{c}\text { H1 } \\
\text { diterima }\end{array}$ & Signifikan \\
\hline \multicolumn{7}{|c|}{ Sumber: Hasil Olahan Data Penulis (2021) } \\
\hline
\end{tabular}

Tabel tersebut menunjukkan hasil pengujian mengenai hubungan antara sub variabel atensi secara mandiri dengan variabel Minat menjadi reporter. Hasil tersebut menunjukkan nilai koefisien korelasi dengan angka 0,710 yang berada diantara 0,600-0,799. Angka tersebut dapat diartikan bahwa sub variabel atensi memiliki tingkat hubungan yang kuat dan positif dengan variabel Minat menjadi reporter.

Hubungan Atensi Penonton Drama Serial X dengan Minat Menjadi Reporter pada Mahasiswa Ilmu Komunikasi Unisba Angkatan 2017.

Pada hasil pengolahan data yang telah dilakukan sebelumnya menghasilkan tanggapan responden mahasiswa fakultas Ilmu Komunikasi Universitas Islam Bandung tahun 2017 menyatakan bahwa mereka memiliki keteratarikan akan tayangan drama tersebut.

Atensi yang dimaksudkan adalah segala bentuk perhatian penonton, ketertarikan penonton, kemudahan dalam memahami, hingga daya tarik tayangan yang diterima oleh berbagai indera manusia hingga kepada sistem sensorik, memori dan proses kognitif. (Sudibyo, 2018).

Ditambahkan oleh penjelasan dari Herly (2018) menyatakan bahwa perhatian adalah proses ketika kesadaran individu terfokus kepada satu objek. Perhatian terjadi jika individu mengkonsentrasikan inderanya pada kejadian yang diamatinya. Sesuatu yang diamati bisa berupa keadaan, situasi, dan juga model (individu lain).

Maka dari itu, dapat diketahui bahwa titik fokus responden pada tayangan drama $X$ ini didorong dengan adanya ketertarikan atas drama tersebut sehingga dapat menghasilkan sebuah perhatian dalam diri responden. Melalui atensi responden untuk menyaksikan tayangan drama $X$ tersebut menimbulkan adanya hubungan yang signifikan dengan minat responden untuk menjadi seorang reporter.

\section{Kesimpulan}

Bagian ini akan menjelaskan mengenai kesimpulan dari hasil pembahasan penelitian yang sudah dipaparkan oleh peneliti pada bagian sebelumnya. Berikut ini adalah beberapa poin yang dapat peneliti simpulkan:

1. Sebagian besar responden menyatakan tanggapan yang positif terhadap tayangan drama $\mathrm{X}$. Adanya tayangan drama tersebut memiliki pengaruh yang kuat dan signifikan terhadap minat mahasiswa fakultas Ilmu Komunikasi Universitas Islam Bandung angkatan 2017 untuk menjadi seorang reporter.

2. Sebagian besar responden menyatakan memiliki frekuensi menonton tayangan drama $X$ yang cukup sering. Seringnya responden menonton tayangan drama tersebut memiliki pengaruh yang kuat dan signifikan terhadap minat mahasiswa fakultas Ilmu Komunikasi Universitas Islam Bandung angkatan 2017 untuk menjadi seorang reporter.

3. Sub variabel metode penyajian tayangan drama $X$ sudah dinilai baik oleh sebagian besar responden. Metode penyajian tayangan drama tersebut memiliki pengaruh yang kuat dan signifikan terhadap minat mahasiswa fakultas Ilmu Komunikasi Universitas Islam Bandung angkatan 2017 untuk menjadi seorang reporter.

4. Sebagian besar responden memberikan tanggapan yang positif terkait durasi mereka menonton tayangan drama X. Lamanya durasi yang mereka habiskan untuk menonton tayangan drama tersebut memiliki pengaruh yang kuat dan signifikan terhadap minat mahasiswa fakultas Ilmu Komunikasi Universitas Islam Bandung angkatan 2017 untuk menjadi seorang reporter. 
5. Atensi sebagian besar responden terhadap tayangan drama $X$ ini dinyatakan baik dengan adanya tanggapan yang positif. Adanya atensi dan ketertarikan responden terhadap tayangan drama tersebut memiliki pengaruh yang kuat dan signifikan bagi minat mahasiswa fakultasn Ilmu Komunikasi Universitas Islam Bandung angkatan 2017 untuk menjadi seorang reporter.

\section{Daftar Pustaka}

[1] Ardianto, E., \& Komala Erdinaya, L. Komunikasi Massa (Bandung: Simbiosa Rekatama Media, 2004)

[2] Sugiono, Ilmu, Metode Penelitian Kuantitatif Kualitatif dan R \& D (Bandung: Alfabeta, 2012), hlm 45

[3] Sugiono, Ilmu, Metode Penelitian Kuantitatif Kualitatif dan R \& D (Bandung: CV Alfabeta, 2019), hlm 397

[4] Anshori \& Iswati, S. Metodologi Penelitian Kuantitatif (Surabaya:Airlangga University Press, 2019)

[5] Sudibyo, R. H. (2018). Pengaruh Terpaan Iklan Rokok Terhadap Minat Beli Konsumen Rokok. Skripsi Fakultas Ekonomi, 121.

[6] Riawati, D. P., \& Hernawati, R. (2016). Hubungan antara Tayangan Drama Korea di Media Online dengan Minat Penonton dalam Mengenal Budaya Korea Selatan. Prosiding Public Relations Universitas Islam Bandung, 2(1), 89-94.

[7] Elendiana, M. (2020). Upaya Meningkatkan Minat Baca Siswa Sekolah Dasar. Jurnal Pendidikan Dan Konseling (JPDK), 1(2), 63-68.

[8] Izzatunihlah. (2017). Pengaruh Terpaan Tayangan Drama Korea Pinocchio Terhadap Minat Mahasiswa Menjadi Jurnalis. Skripsi Fakultas Ilmu Sosial Dan Ilmu Politik, 237.

[9] Lesilolo, H. J. (2019). Penerapan Teori Belajar Sosial Albert Bandura Dalam Proses Belajar Mengajar Di Sekolah. KENOSIS: Jurnal Kajian Teologi, 4(2), 186-202. https://doi.org/10.37196/kenosis.v4i2.67

[10] Munawwaroh, P. R. (2013). Pengaruh Terpaan Media Pada Akun Instagram @exploresiak Terhadap Minat Kunjungan Wisata ke Siak Sri Indrapura. Jom Fisip, 5(1), 1-13.

[11] Primawan, Y. T. (2009). Mekanisme Kerja Reporter Kompas TV. Skripsi Komunikasi Terapan, 49.

[12] Rakmawati, J., Santi, D. P. D., \& Khomarruzaman, K. (2020). Karakter Siswa Kelas IV Sekolah Dasar di Kota Cirebon. Caruban: Jurnal Ilmiah Ilmu Pendidikan Dasar, 3(2), 154. https://doi.org/10.33603/caruban.v3i2.4321 